it may be a comparative work in the context of any language, carried out by Czech scholars as well as by scholars from abroad, native-speakers as well as non-native speakers of English; this book is a useful source that may facilitate their work and provide them with reliable methodological as well as material basis.

Michal Kř́stek

https://doi.org/10.5817/OS2018-4-9

\title{
Záslužný vydavatelský počin: první knižní vydání cenné, avšak téměr̆ zapomenuté práce o vývoji východo- slovenských nářečí
}

KOTULIČ, I.: Historické hláskoslovie a tvaroslovie východoslovenských náreči (1957). Bratislava: Veda, 2017. ISBN 978-80-224-1582-8.

V roce 2017 vydal Jazykovedný ústav L'udovíta Štúra SAV v rámci projektu Fonologický vývin slovenčiny vo svetle súčasného stavu historickej jazykovedy kandidátskou disertační práci slovenského jazykovědce PhDr. Izidora Kotuliče, CSc., (1927-2012) Historické hláskoslovie a tvaroslovie východoslovenských nárečí z roku 1957. Kniha byla vydána $\mathrm{k}$ devadesátému výročí autorova narození.

Jedná se o první knižní vydání práce, která dosud byla badatelům známá pouze z četných bibliografických odkazů v monografii Kotuličova učitele a školitele prof. Eugena Paulinyho Fonologický vývin slovenčiny ${ }^{1}$ (a jejím prostřednictvím sekundárně i z dalších prací). Bohužel bylo téměř nemožné nahlédnout do Kotuličovy dizertace, protože se nenacházela $\mathrm{v}$ žádné veřejné ani akademické knihovně na Slovensku. Nynější vydání díla bylo možné jen díky ochotě Kotuličovy rodiny, která zapůjčila soukromý exemplář rukopisu.

Kotulič sám se k přípravě textu pro knižní vydání bohužel nikdy nedostal. To by vyžadovalo další usilovnou a časově náročnou práci, bylo by potřeba vypořádat se s připomínkami oponentů, tedy provést v textu řadu formálních i koncepčních změn. V neposlední řadě byla komplikací i absence závěru, který do termínu odevzdání práce autor nestihl vypracovat. Po získání vědecké hodnosti se Kotulič začal věnovat náročnému a dlouhodobému procesu budování základny pro Historický slovník

1 PAULINY, E.: Fonologický vývin slovenčiny. Bratislava: Vydavatel'stvo Slovenskej akadémie vied, 1963. 
slovenského jazyka (byl spoluautorem prvních tří dílů), $\mathrm{k}$ tomu zastával různé vědecko-organizační funkce (1959-1965 zástupce ředitele Ústavu slovenského jazyka SAV, 1962-1969 a 1981-1983 vedoucí oddělení dějin slovenského jazyka, 1959-1970 výkonný redaktor Jazykovědného časopisu).

Představovanou publikaci uvádí předmluvou (s. 7-13) editor dr. sc. Siniša Habijanec, $\mathrm{PhD}$. Následuje samotná práce Izidora Kotuliče, která je členěna do tří samostatných celků: Úvod (s. 15-27), Hláskoslovie (s. 28-117) a Tvaroslovie (s. 118-231).

V Úvodu Kotulič objasňuje, že vývoj východní slovenštiny sleduje přibližně od 11.-12. století, tj. od prvních písemných záznamů jazykového materiálu z této oblasti, pouze do konce 17. století, jelikož prozkoumaný historický materiál ukazuje, že na východním Slovensku se od 17 . století mluvilo v podstatě stejným nářečím jako dnes, $\mathrm{k}$ žádným větším změnám nedošlo (pouze k pronikání starších vývojových změn dále do okrajových nářečí). Součástí Úvodu je též hláskoslovná a tvaroslovná charakteristika východoslovenské nářeční skupiny, která se dělí na nářečí spišské, šarišské, abovské a zemplínské.

Následující kapitola Hláskoslovie popisuje vývoj východoslovenského vokalického a konsonantického systému. $\mathrm{V}$ kapitole Tvaroslovie se autor věnuje ohebným druhům slov: substantivům, adjektivům, zájmenům, číslovkám a slovesům.

Na s. 233-235 nalezneme Seznam zkratek a značek, na s. 237-241 Zkratky pramenů, Kotuličovu práci uzavírá oddíl Použitá literatura (s. 243-250).

O problémech technického a formálního charakteru při digitalizaci textu disertace nás seznamuje Slovo editora (s. 251-254). Kotulič psal svoji práci na psacím stroji, na němž samozřejmě nebyly $\mathrm{k}$ dispozici speciální grafické znaky (např. dlouhé å), proto je do textu dodatečně dopisoval ručně, avšak ne vždy jednoznačně a důsledně, $\mathrm{v}$ mnoha prípadech bylo tedy třeba je rekonstruovat z kontextu. Práce také obsahovala velké množství lexikálních a syntaktických bohemismů, patrný byl i vliv autorova rodného šarišského nářečí, proto byl jazyk knižního vydání přizpůsoben současnému standardnímu úzu, aby dnešní čtenář neměl potíže s porozuměním textu. Byla sjednocena vědecká transkripce nářečních záznamů, která byla v původním textu do jisté míry rozkolísaná (např. hláska či foném ch se v editovaném textu důsledně zapisuje jako $x$ ). Při počítačovém zpracování textu psaného na psacím stroji nebylo možné zachovat stejné rozložení stran, avšak s ohledem na citace Kotuličovy práce v díle Paulinyho i jiných autorů označili tvůrci knihy původní paginaci číslicí na vnějším okraji stránky na úrovni slova, kterým začínala příslušná stránka v rukopisu. Odkazy v samotném textu jsou však již přizpůsobeny novému stránkování. Součástí

2 Historický slovník slovenského jazyka. Bratislava: Veda, 1991-2008. ISBN 80-224-0228-1 (A - J); ISBN 80-224-0385-7 (K - N); ISBN 80-224-0429-2 (O - pochytka); ISBN 80-224-0432-2 (poihrat sa pytlovat); ISBN 80-224-0628-7 (R - S); ISBN 80-224-0862-X (T - V); ISBN 978-80-224-1003-8 (Z - Z̆; Dodatky). 
kandidátské práce byla původně i př́loha, obsahující nejméně deset jazykových map, ta se však pravděpodobně do současnosti nezachovala, $\mathrm{z}$ tohoto důvodu byly všechny autorovy odkazy na přiložené mapy z textu vymazány. Práce kromě závěru neobsahovala ani cizojazyčné resumé, proto tvůrci knihy připojili k textu krátký souhrn v angličtině (s. 263-265), v němž uvádějí základní body Kotuličovy koncepce vývoje východoslovenských nářečí a podávají stručné celkové hodnocení díla. Představovanou publikaci uzavírá Obsah (s. 267-269).

Knižním vydáním kandidátské práce se zaplnila velká mezera v slovenské historické jazykovědě a v slovenské dialektologii. Velkou část disertace tvoří četné nářeční a historické jazykové záznamy, které Kotulič bud’ excerpoval z publikovaných pramenů, nebo získal vlastními terénními sběry či bádáním v archivech. Excerpoval historické dokumenty $\mathrm{v}$ téměř všech východoslovenských a relevantních budapeštských archivech. Takto získané údaje představují velmi cenný př́nos disertace a zcela jistě budou užitečné i pro další badatele.

Dobrou zprávou pro všechny zájemce o kandidátskou práci Izidora Kotuliče je její dostupnost též v elektronické podobě na adrese <http://www.academia.edu/34892007/ Historické_hláskoslovie_a_tvaroslovie_východoslovenských_nárečí_1957_>.

Petra Přadková

https://doi.org/10.5817/OS2018-4-10

\section{Znovu o kouzlu překladu}

KREJČOVÁ, E., STALYANOVA, N.: Kouzlo a umění překladu. Brno: Masarykova univerzita, 2018, 80 s., ISBN 978-80-210-9017-0.

Profese prrekladatele a tlumočníka je výzvou pro každého, kdo se rozhodl se jí věnovat. Vyžaduje totiž jak talent, tak i velmi dobré ovládání nejen jazyka, z/do kterého se překládá, ale i vlastní mateřštiny. Překladatel musí mít široký rozhled, specifické znalosti a ovládat alespoň do určitého stupně terminologie nejrůznějších oblastí života. Každý filolog se dříve či později „osobně setká“ s překladem a toto setkání někdy přeroste v jeho profesní životní lásku. Právě pro filology - studenty bulharštiny na zahraničních univerzitách, kteří se seznamují s tajemstvími překládání a to jak specializovaných textů, tak i odborné literatury - je určena príručka Kouzlo a umění prekladu, která vyšla v předvečer Mezinárodního dne překladatelů (3o. záŕí svátek sv. Jeronýma, patrona překladatelů). Díky jejímu zpř́stupnění online v digitální číárně Masarykovy univerzity je knížka př́stupná nejen kmenovým studentům MU, ale každému, kdo o ni ve virtuálním světě projeví zájem. 